\title{
Effects of testicular dysgenesis syndrome components on testicular germ cell tumor prognosis and oncological outcomes
}

\author{
Ismail Selvi ${ }^{1}$, Erdem Ozturk ${ }^{2}$, Taha Numan Yikilmaz ${ }^{2}$, Selcuk Sarikaya ${ }^{3}$, Halil Basar ${ }^{2}$ \\ ${ }^{1}$ Department of Urology, Karabük University Training and Research Hospital, Karabük, Turkey; ${ }^{2}$ Department \\ of Urology, Health Science University Dr. Abdurrahman Yurtaslan Ankara Oncology Training and Research \\ Hospital, Ankara, Turkey; ${ }^{3}$ Department of Urology, Health Science University Gulhane Training and \\ Research Hospital, Ankara, Turkey
}

\section{ABSTRACT}

Purpose: To evaluate whether components of Testicular Dysgenesis Syndrome (TDS) affect testicular germ cell tumor (TGCT) prognosis and oncological outcomes. According to the hypothesis called TDS; undescended testis, hypospadias, testicular cancer and spermatogenic disorders share the same risk factors and have a combined fetal origin. Materials and Methods: We retrospectively evaluated the stages and oncological outcomes of 69 patients who underwent radical orchiectomy between January 2010 and December 2014 due to TGCT in our department. The presence of undescended testis, hypospadias and semen parameters disorders were recorded according to anamnesis of patients. Results: Among 69 patients with TGCT, only $16(23.1 \%)$ had TDS. Significantly higher rate of TDS (36.1\% vs. 9.1\%) was observed at the advanced stages of TGCT(p=0.008). In the TDS group, the rates of local recurrence (50\% vs. $11.3 \%, p<0.001)$, distant metastasis $(93.6 \%$ vs. $3.8 \%, \mathrm{p}<0.001)$ and cancer-spesific mortality $(87.5 \%$ vs. $3.8 \%$, $\mathrm{p}<0.001$ ) were found significantly higher than those without TDS. The predicted time for recurrence-free survival $(13.70 \pm 5.13$ vs. $100.96 \pm 2.83$ months, $p<0.001)$ metastasis-free survival $(13.12 \pm 4.21$ vs. $102.79 \pm 2.21$ months, $p<0.001)$ and cancer-specific survival ( $13.68 \pm 5.38$ vs. $102.80 \pm 2.19$ months, $\mathrm{p}<0.001)$ were also statistically lower in this group. Conclusions: According to our preliminary results, there is an apparent relationship between TDS and tumor prognosis. Even if the components of TDS alone did not contain poor prognostic features for TGCT, the presence of TDS was found as the most important independent predictive factor for oncological outcomes in both seminomas and nonseminomas as well as all patients with TGCT.

\section{ARTICLE INFO}

Ismail Selvi

http://orcid.org/0000-0003-3578-0732

Keywords:

Cryptorchidism; Testicular Germ

Cell Tumor [Supplementary

Concept]; Hypospadias

Int Braz J Urol. 2020; 46: 725-40

Submitted for publication:

June 11, 2019

Accepted after revision:

November 14, 2019

Published as Ahead of Print:

April 01, 2020

\section{INTRODUCTION}

Testicular dysgenesis syndrome (TDS) is one of the current topics that has been described in recent years. Undescended testis, hypospadias, decreased spermatogenesis and testicular germ cell tumor (TGCT) form TDS components (1). One or more of these disorders occur in about 1 in 6 young men in Northern Europe (2). TDS has a common fetal origin associated with deficiencies 
in fetal androgen production (3). A failure in normal differentiation of fetal germ cells is effective in the formation of this syndrome. Increase in the incidence of TGCT in young men is also related to this mechanism. That is why TDS have been associated with TGCT (1). The hypotheses related to TDS have been strengthened by new studies since the last two decades $(4,5)$. Althought there are still controversial views about TDS, these studies have aimed to provide evidence verifying the reality of TDS based on a few key aspects, such as genetic factors, environmental endocrine-disrupting chemicals, lifestyle factors and intrauterine growth disorders $(6,7)$.

The biological mechanism of TDS was tried to be demonstrated in animal models due to limitations in human studies (4). Nevertheless, more evidence is needed to reinforce TDS hypothesis (8). According to the literature, semen analysis and testicular histology support the association between TGCT and TDS (9). But there is no detailed evaluation to show the effects of TDS components on TGCT prognosis. We aimed to evaluate whether components of TDS have an effect on TGCT prognosis and oncological outcomes.

\section{MATERIALS AND METHODS}

After obtaining the approval of the local ethics committee (protocol number: 77192459050.99-E.2812, 3/19), we retrospectively evaluated the stages and oncological outcomes of 77 patients who underwent radical orchiectomy between January 2010 and December 2014 due to TGCT at our department. The presence of undescended testis, hypospadias, disorders of semen parameters and atrophic testis (testicular volume $<12 \mathrm{~mL}$ ) were recorded. As our study also included non-married patients, it was not possible to evaluate the fertility status for all patients. Instead of this, disorders of semen parameters were examined. Demographic data, histological tumor types, clinical stages, tumor side, tumor sizes, expression of serum tumour markers (Alpha-fetoprotein, Beta human chorionic gonadotropin $[\beta-\mathrm{hCG}]$ and Lactate dehydrogenase [LDH]), prognostic factors in pathology specimen, post-orchiectomy follow-up period, presence of adjuvant therapy after orchiectomy, rates of local recurrence, distant metastasis and cancer-specific survival (CSS) were also recorded. 69 patients with complete data were included in the study. The patients whose data could not be completely collected were excluded from the study.

Tumor stages were recorded according to the 2009 classification of Tumor-Node-Metastasis. Patients were divided into two main groups. Stage IA and IB were determined as early stage (Group I). Stage IS, IIA/IIB/IIC and IIIA/IIIB/IIIC were determined as advanced stage (Group II).

The definition of TDS involves the presence of at least two of the following: undescended testis, hypospadias, decreased spermatogenesis and testicular germ cell tumor (4). As all patients had TGCT, those with any of undescended testis, hypospadias or disorders of semen parameters formed the TDS group. 16 patients with TDS and 53 patients without TDS were determined and a subgroup analysis was also done.

Pathological prognostic factors were based on the Guidelines of European Association of Urology on Testicular Tumors (9).The prognostic factors for the stage I seminomas were rete testis involvement and tumor size greater than $4 \mathrm{~cm}$.The presence of lymphovascular invasion (LVI), the percentage of embryonal carcinoma more than $50 \%$ and the proliferation rate above $70 \%$ were prognostic factors for stage I non-seminomas.

\section{Statistical analysis}

To compare the differences between the two groups, the normality status was evaluated by Kolmogorov-Smirnov and Shapiro-Wilk tests. Pearson Chi-square or Fisher exact analysis for categorical variables, Mann-Whitney U test for continuous variables in non-normal distribution were used. Kaplan-Meier was used for survival analysis and Cox regression analysis was used for determining the independent variables. The analyzes were performed using IBM SPSS Statistics 21 (IBM, Armonk, NY USA) software. $\mathrm{P}<0.05$ was considered statistically significant.

\section{RESULTS}

Median age of the 69 male patients was 31 (min:8-max:60). Demographic and clinical cha- 
racteristics of the patients are shown in Tables 1 and 2. During the median follow-up period of 57 (6-106) months, the distant metastases were located at lung in 8 patients, liver in 4 patients and non-regional lymph nodes in 5 patients.

When the early and advanced tumor stages were compared, it was shown that the predicted time for recurrence-free survival (RFS) $(71.61 \pm 8.02$ vs. $96.57 \pm 4.65$ months, $p=0.01)$, metastasis-free survival (MFS) $(68.32 \pm 7.91$ vs. $96.99 \pm 4.43$ months, $p=0.003)$ and cancer-specific survival CSS $(71.18 \pm 7.73$ vs. $96.67 \pm 4.57$ months, $\mathrm{p}=0.007$ ) were statistically lower in patients with advanced stage (Figures 1A, 1B and 1C).

In a subgroup analysis, patients were classified in terms of the presence of TDS. Significantly higher TDS rates (36.1\% vs. 9.1\%) were observed in the advanced stages $(p=0.008)$ (Table-2). In the TDS group, the rates of loctal recurrence ( $50 \%$ vs. $11.3 \%, p<0.001$ ), distant metastasis $(93.6 \%$ vs. $3.8 \%, p<0.001)$ and cancer-specific mortality $(87.5 \%$ vs. $3.8 \%$, p $<0.001$ ) were found significantly higher than those without TDS (Table-3). When patients with seminoma and non-seminoma were compared between themselves, in the presence of TDS, the rate of local recurrence $(88.9 \%$ vs. $57.1 \%)$ was higher in non-seminomas, whereas distant metastasis (100\% vs. 88.9\%) and cancer-specific mortality rates $(100 \%$ vs. $77.8 \%)$ were higher in seminomas (Table-3).

The predicted time for recurrence-free survival (RFS) (13.70 \pm 5.13 vs.100.96 \pm 2.83 months, p <0.001), metastasis-free survival (MFS) $(13.12 \pm 4.21$ vs. $102.79 \pm 2.21$ months, $p<0.001)$ and cancer-specific survival (CSS) $(13.68 \pm 5.38$ vs. $102.80 \pm 2.19$ months, $p<0.001)$ were statistically lower in patients with TDS (Figures 2A, $2 \mathrm{~B}$ and $2 \mathrm{C}$ ). In the presence of TDS, the predicted time for RFS was longer in patients with seminoma $(13.64 \pm 4.56$ vs. $12.66 \pm 6.48$ months, $p$ $<0.001)$. Conversely, the predicted time for MFS

Table 1 - Distribution of patients according to tumor stages, histologic tumor types, components of testicular dysgenesis syndrome and oncologic outcomes.

\begin{tabular}{|c|c|c|c|c|c|c|c|c|c|c|c|c|c|}
\hline Stage & $\begin{array}{c}\text { Number of } \\
\text { seminoma } \\
\text { patients }\end{array}$ & $\begin{array}{c}\text { Number } \\
\text { of non- } \\
\text { seminoma } \\
\text { patients }\end{array}$ & $\begin{array}{l}\text { Number of } \\
\text { mix germ } \\
\text { cell tumor }\end{array}$ & $\begin{array}{c}\text { History of } \\
\text { undescended } \\
\text { testis }\end{array}$ & $\begin{array}{c}\text { History of } \\
\text { hypospadiass }\end{array}$ & $\begin{array}{l}\text { History of } \\
\text { subfertility }\end{array}$ & $\begin{array}{l}\text { Numbers of } \\
\text { patients with } \\
\text { testicular } \\
\text { dysgenesis } \\
\text { syndrome }\end{array}$ & $\begin{array}{l}\text { Post- } \\
\text { treatment } \\
\text { recurrence } \\
\text { and } \\
\text { histological } \\
\text { subtype }\end{array}$ & $\begin{array}{l}\text { Presence } \\
\text { of testicular } \\
\text { dysgenesis } \\
\text { syndrome in } \\
\text { patients with } \\
\text { recurrence }\end{array}$ & $\begin{array}{l}\text { Post- } \\
\text { treatment } \\
\text { metastasis } \\
\text { and } \\
\text { histological } \\
\text { subtype }\end{array}$ & $\begin{array}{l}\text { Presence } \\
\text { of testicular } \\
\text { dysgenesis } \\
\text { syndrome in } \\
\text { patients with } \\
\text { metastasis }\end{array}$ & $\begin{array}{l}\text { Post-treatment } \\
\text { mortality and } \\
\text { histological } \\
\text { subtype }\end{array}$ & $\begin{array}{c}\text { Presence } \\
\text { of testicular } \\
\text { dysgenesis } \\
\text { syndrome } \\
\text { in deceased } \\
\text { patients }\end{array}$ \\
\hline IA & 11 & 4 & 5 & - & - & - & $0(\% 0)$ & 0 & $0(\% 0)$ & 1 (NS) & $0(\% 0)$ & 1 (NS) & $0(\% 0)$ \\
\hline IB & 8 & 4 & 1 & 2 & - & 2 & $3(\% 23)$ & 2 (NS) & $1(\% 50)$ & $1(\mathrm{M}), 1(\mathrm{~S})$ & $2(\% 100)$ & $1(\mathrm{M}), 1(\mathrm{~S})$ & $2(\% 100)$ \\
\hline IS & 1 & 1 & 2 & - & - & - & $0(\% 0)$ & $1(\mathrm{M})$ & $0(\% 0)$ & 0 & & 0 & \\
\hline IIA & 0 & 1 & 0 & - & - & - & $0(\% 0)$ & 0 & $0(\% 0)$ & 0 & & 0 & \\
\hline IIC & 3 & 0 & 0 & 1 & 1 & - & $1(\% 33.3)$ & $1(\mathrm{~S})$ & $1(\% 100)$ & $2(S)$ & $1(\% 50)$ & $2(S)$ & $1(\% 50)$ \\
\hline IIIA & 1 & 2 & 0 & - & - & 1 & $1(\% 33.3)$ & 1 (NS) & $0(\% 0)$ & 1 (NS) & $1(\% 100)$ & 0 & \\
\hline IIIB & 5 & 3 & 1 & 2 & & 2 & $4(\% 44.4)$ & 2 (NS), 1 (S) & $2(\% 66.6)$ & 2(S), 2(NS) & $4(\% 100)$ & 2(S), 2(NS) & $4(\% 100)$ \\
\hline IIIC & 6 & 6 & 0 & 3 & 2 & 3 & $6(\% 50)$ & 2 (S), 3 (NS) & $4(\% 80)$ & 3(NS), 3(S) & $6(\% 100)$ & 3(NS), 3(S) & $6(\% 100)$ \\
\hline $\begin{array}{l}\text { Total } \\
\text { number }\end{array}$ & 35 & 24 & 10 & 9 & 3 & 9 & $16(\% 23.1)$ & 14 & $8(\% 57.1)$ & 17 & $15(\% 88.2)$ & 16 & $14(\% 87.5)$ \\
\hline
\end{tabular}

$\mathbf{S}=$ Seminoma, $\mathbf{N S}=$ Non-seminoma; $\mathbf{M}$ = Mix germ cell tumor 
Table 2 - Demographic, pathological, clinical data and oncologic outcomes of the patients.

\begin{tabular}{|c|c|c|c|c|}
\hline \multirow[t]{2}{*}{ Parameters } & Group I & Group II & Total & $p$ value \\
\hline & $\begin{array}{c}\text { (Early stage TGCT) } \\
(\mathrm{n}: 33)\end{array}$ & $\begin{array}{c}\text { (Advanced stage TGCT) } \\
(\mathrm{n}: 36)\end{array}$ & $(n: 69)$ & \\
\hline \multicolumn{5}{|l|}{ Age } \\
\hline $\begin{array}{l}\text { Median ( } 25^{\text {th }} \text { - } \\
75^{\text {th }} \text { percentiles) }\end{array}$ & $31.00(27.00-37.00)$ & $30.00(24.25-41.75)$ & $31(25-40)$ & $\dagger 0.709$ \\
\hline \multicolumn{5}{|l|}{ Tumor size (cm) } \\
\hline $\begin{array}{l}\text { Median (25 } \\
75^{\text {th }} \text { - } \\
\text { percentiles) }\end{array}$ & $3.50(2.15-4.55)$ & $5.55(3.52-7.20)$ & $4.20(2.65-6.50)$ & $\dagger 0.002^{*}$ \\
\hline \multicolumn{5}{|l|}{ Tumor laterality (n,\%) } \\
\hline Left & $10(30.3)$ & $13(36.1)$ & $23(33.3)$ & $\ddagger 0.877$ \\
\hline Right & $21(63.6)$ & $21(58.3)$ & $42(60.9)$ & \\
\hline Bilateral & $2(6.1)$ & $2(5.6)$ & $4(5.8)$ & \\
\hline \multicolumn{5}{|c|}{ Histopathological subtype(n,\%) } \\
\hline Seminoma & $19(57.6)$ & $16(44.4)$ & $35(50.7)$ & \\
\hline Non-seminoma & $8(24.2)$ & $16(44.4)$ & $24(34.8)$ & $\ddagger 0.202$ \\
\hline Mix & $6(18.2)$ & $4(11.1)$ & $10(14.5)$ & \\
\hline \multicolumn{5}{|l|}{$\operatorname{AFP}(\mathrm{ng} / \mathrm{mL})$} \\
\hline $\begin{array}{l}\text { Median ( } 25^{\text {th }} \text { - } \\
75^{\text {th }} \text { percentiles) }\end{array}$ & $5.00(1.70-10.70)$ & $6.90(2.75-354.25)$ & $5.50(2.15-74.37)$ & $\dagger 0.058$ \\
\hline \multicolumn{5}{|l|}{$\beta$-hCG (mIU/mL) } \\
\hline $\begin{array}{l}\text { median ( } 25^{\text {th }} \text { - } \\
75^{\text {th }} \text { percentiles) }\end{array}$ & $4.90(1.30-33.30)$ & $62.10(5.95-911.02)$ & $15.20(2.50-128.00)$ & $\dagger 0.005^{\star}$ \\
\hline \multicolumn{5}{|l|}{ LDH (U/I) } \\
\hline $\begin{array}{l}\text { Median ( } 25^{\text {th }} \text { - } \\
75^{\text {th }} \text { percentiles) }\end{array}$ & $\begin{array}{c}208.00(155.00- \\
266.00)\end{array}$ & $717.00(330.00-1299.25)$ & $\begin{array}{c}309.00(202.00- \\
740.00)\end{array}$ & $\dagger<0.001^{*}$ \\
\hline \multicolumn{5}{|l|}{ ITGCN (n,\%) } \\
\hline Present & $15(45.5)$ & $20(55.6)$ & $35(50.7)$ & $\ddagger 0.402$ \\
\hline Absent & $18(54.5)$ & $16(44.4)$ & $34(49.3)$ & \\
\hline \multicolumn{5}{|c|}{ Rete testis involvement ( $\mathrm{n}, \%)$} \\
\hline Present & $8(24.2)$ & $7(19.4)$ & $15(21.7)$ & $\ddagger 0.629$ \\
\hline Absent & $25(75.8)$ & $29(80.6)$ & $54(78.3)$ & \\
\hline
\end{tabular}

Tumor diameter> $4 \mathrm{~cm}(\mathrm{n}, \%)$ 


$\begin{array}{lllll}\text { Yes } & 12(36.4) & 24(66.7) & 36(52.2) & \ddagger 0.012^{*} \\ \text { No } & 21(63.6) & 12(33.3) & 33(47.8) & \\ \text { phovascular invasion }(\mathbf{n}, \%) & & & & \\ \text { Present } & 7(21.2) & 20(55.6) & 27(39.1) & \ddagger 0.004^{*} \\ \text { Absent } & 26(78.8) & 16(44.4) & 42(60.9) & \end{array}$

Embryonal carcinoma rate $>\mathbf{5 0 \%}$ $(n, \%)$

Present $7(21.2)$

Absent

$26(78.8)$

Proliferation rate $>70 \%(n, \%)$

$\begin{array}{lr}\text { Present } & 3(9.1) \\ \text { Absent } & 30(90.9)\end{array}$

Undescended testis ( $\mathrm{n}, \%)$

$\begin{array}{lc}\text { Present } & 2(6.1) \\ \text { Absent } & 31(93.9)\end{array}$

$7(19.4)$

$29(80.6)$

$12(33.3)$

$24(66.7)$

$19(27.5)$

$\ddagger 0.260$

$50(72.5)$

7 (19.4)

$29(80.6)$

$10(14.5)$

$\ddagger 0.222$

$59(85.5)$

$9(13.0)$

$\ddagger 0.099$

Disorders of semen

parameters(n,\%)

Present

$2(6.1)$

7 (19.4)

$29(80.6)$

$9(13.0)$

$\ddagger 0.099$

Absent

31 (93.9)

Hypospadias ( $n, \%)$

Present

$0(0.0)$

Absent

$33(100.0)$

$3(8.3)$

$33(91.7)$

$3(4.3)$

$\S 0.240$

Atrophic testis (n,\%)

Present

Absent

$1(3.0)$

$32(97.0)$

$6(16.7)$

7 (10.1)

$\ddagger 0.061$

Presence of TDS $(n, \%)$

\begin{tabular}{|c|c|c|c|c|}
\hline Present & $3(9.1)$ & $13(36.1)$ & $16(23.2)$ & $\ddagger 0.008^{*}$ \\
\hline Absent & $30(90.9)$ & $23(63.9)$ & $53(76.8)$ & \\
\hline Local recurrence rate $(\mathrm{n}, \%)$ & $2(6.1)$ & $12(33.3)$ & $14(20.3)$ & $\ddagger 0.015^{\star}$ \\
\hline Distant metastasis rate $(\mathrm{n}, \%)$ & $3(9.1)$ & $14(38.9)$ & $17(24.6)$ & $\ddagger 0.004^{*}$ \\
\hline Cancer-specific survival rate (\%) & 90.9 & 63.9 & 76.8 & $\ddagger 0.008^{*}$ \\
\hline
\end{tabular}


Figure 1A - KKaplan-Meier plots of recurrence-free survival according to the early and advanced stages for all tumors.

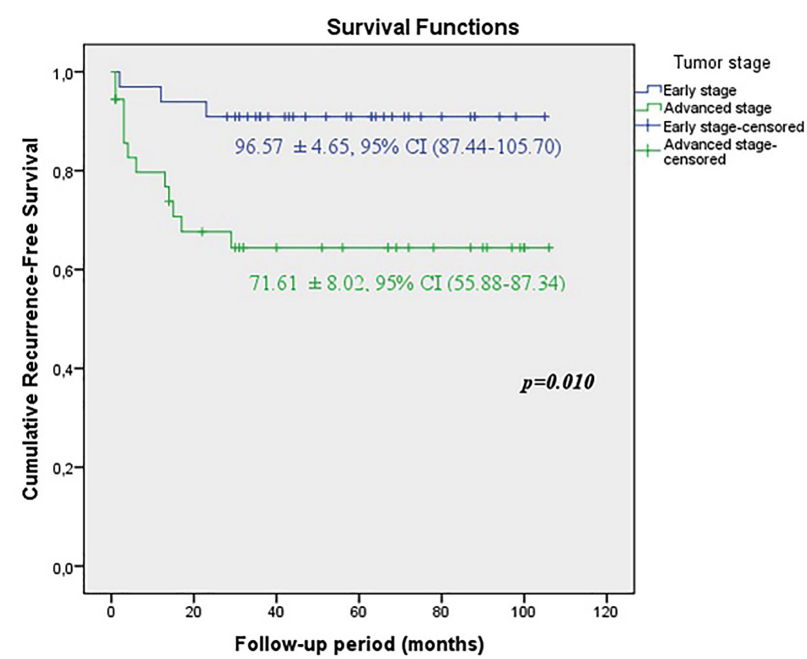

Figure 1B - Kaplan-Meier plots of cancer-specific survival according to the early and advanced stages for all tumors.

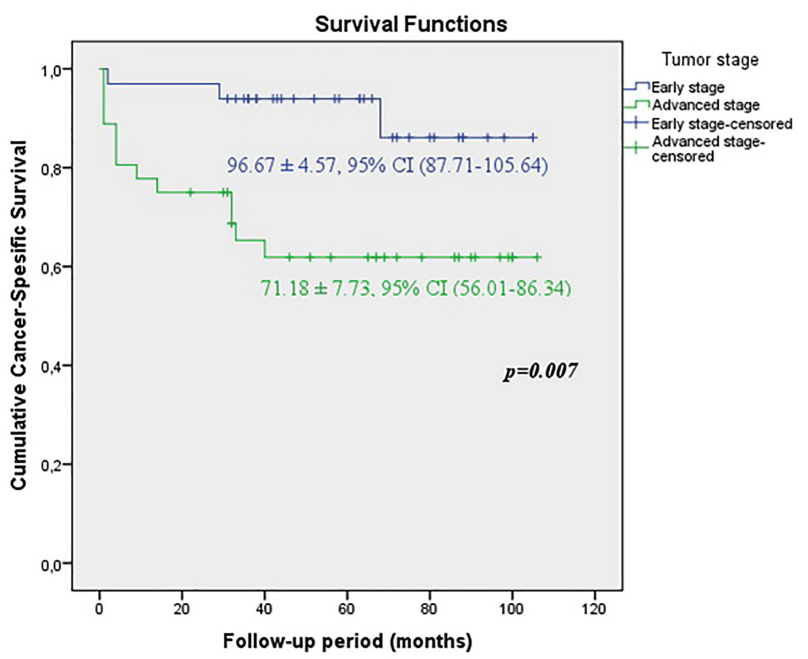

( $9.14 \pm 4.40$ vs. $16.22 \pm 6.59$ months, $\mathrm{p}<0.001)$ and CSS $(11.71 \pm 5.16$ vs. $24.11 \pm 8.39$ months, $p<0.001)$ were statistically shorter in patients with seminoma (Figures 3A, 3B, 3C and Figures 4A, 4B, 4C).

When we evaluated the patients in early and advanced tumor stages, we found that there were no significant differences between the rates of undescended testis, hypospadias and disorders of semen parameters. However, the rate of TDS was found significantly higher
Figure 1C - Kaplan-Meier plots of metastasis-free survival according to the early and advanced stages for all tumors.

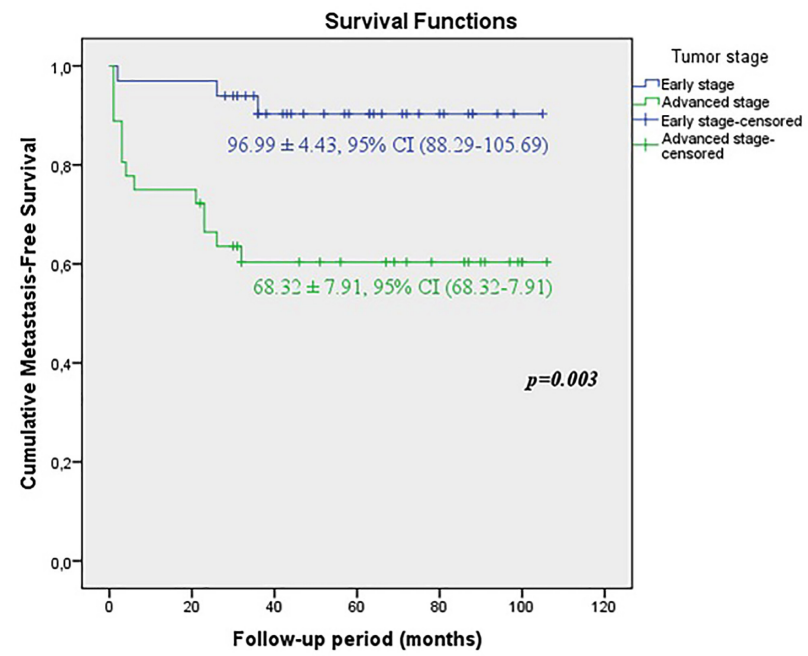

in advanced stage (Table-2).

In univariate analysis, clinical stage, $\beta$-hCG, LDH, the presences of undescended testis, disorders of semen parameters, hypospadias, atrophic testis and TDS were found as independent predictive factors to estimate local recurrence, distant metastasis and cancer-specific survival (CSS). In multivariate analysis, the most important independent predictive factor was TDS to determine local recurrence, distant metastasis and cancer-specific survival RFS, MFS and CSS in both seminomas and nonseminomas as well as all patients with TGCT. In addition, clinical stage was found as a predictive factor for development of distant metastasis in all patients with TGCT (Table-4).

\section{DISCUSSION}

Recent studies in the United States have remarked that TGCT is the most common cancer among men between the ages of 15-44 years and constitutes $98 \%$ of all testis malignancies (10). Undescended testis and hypospadias, which are the other components of TDS, affect 2-9\% and 0.2-1\% of male newborns, respectively (11). Approximately $10-15 \%$ of married couples have infertility and the male factor is responsible for about half of the cases 
Table 3 - Oncologic outcomes of the patients in terms of testicular dysgenesis syndrome.

\begin{tabular}{|c|c|c|c|c|}
\hline All patients with testicular germ cell tumor & Patients with TDS (n:16) & Patients without TDS (n:53) & Total (n:69) & p value \\
\hline \multicolumn{5}{|l|}{ Local recurrence( $(\mathrm{n}, \%)$} \\
\hline Present & $12(75.0)$ & $3(5.7)$ & $16(23.2)$ & $\ddagger<0.001^{*}$ \\
\hline Absent & $4(25.0)$ & $50(94.3)$ & $53(76.8)$ & \\
\hline \multicolumn{5}{|l|}{ Distant metastasis $(\mathrm{n}, \%)$} \\
\hline Present & $15(93.6)$ & $2(3.8)$ & $17(24.6)$ & $\ddagger<0.001^{*}$ \\
\hline Absent & $1(6.3)$ & $51(96.2)$ & $52(75.4)$ & \\
\hline \multicolumn{5}{|l|}{ Cancer spesific mortality (n,\%) } \\
\hline Present & $14(87.5)$ & $2(3.8)$ & $16(23.2)$ & $\ddagger<0.001^{*}$ \\
\hline Absent & $2(12.5)$ & $51(96.2)$ & $53(76.8)$ & \\
\hline Patients with seminoma & Patients with TDS (n:7) & Patients without TDS (n:28) & Total (n:35) & $\mathrm{p}$ value \\
\hline \multicolumn{5}{|l|}{ Local recurrence( $n, \%)$} \\
\hline Present & $4(57.1)$ & $1(3.6)$ & $5(14.3)$ & $\S 0.003^{*}$ \\
\hline Absent & $3(42.9)$ & $27(96.4)$ & $30(85.7)$ & \\
\hline \multicolumn{5}{|l|}{ Distant metastasis $(\mathrm{n}, \%)$} \\
\hline Present & $7(100.0)$ & $1(3.6)$ & $8(22.9)$ & $\S<0.001^{*}$ \\
\hline Absent & $0(0.0)$ & $27(96.4)$ & $27(77.1)$ & \\
\hline \multicolumn{5}{|l|}{ Cancer specific mortality $(\mathrm{n}, \%)$} \\
\hline Present & $7(100.0)$ & $1(3.6)$ & $8(22.9)$ & $\S<0.001^{*}$ \\
\hline Absent & $0(0.0)$ & $27(96.4)$ & $27(77.1)$ & \\
\hline Patients with non-seminoma & Patients with TDS (n:9) & Patients without TDS (n:25) & Total (n:34) & $p$ value \\
\hline \multicolumn{5}{|l|}{ Local recurrence $(n, \%)$} \\
\hline Present & $8(88.9)$ & $1(4.0)$ & $9(26.5)$ & $\S<0.001^{*}$ \\
\hline Absent & $1(11.1)$ & $24(96.0)$ & $25(73.5)$ & \\
\hline \multicolumn{5}{|l|}{ Distant metastasis $(\mathrm{n}, \%)$} \\
\hline Present & $8(88.9)$ & $1(4.0)$ & $9(26.5)$ & $\S<0.001^{*}$ \\
\hline Absent & $1(11.1)$ & $24(96.0)$ & $25(73.5)$ & \\
\hline \multicolumn{5}{|l|}{ Cancer specific mortality (n,\%) } \\
\hline Present & $7(77.8)$ & $1(4.0)$ & $8(23.5)$ & $\S<0.001^{*}$ \\
\hline Absent & $2(22.2)$ & $24(96.0)$ & $26(76.5)$ & \\
\hline
\end{tabular}

${ }^{*}=p<0.05$ Asteriks $\left({ }^{*}\right)$ indicates statistical significance.

TDS $=$ Testicular dysgenesis syndrome

$\ddagger=$ Chi-square test

$\S=$ Fisher's Exact test 
Figure 2A - Kaplan-Meier plots of recurrence-free survival according to presence of Testicular Dysgenesis Syndrome for all patients.

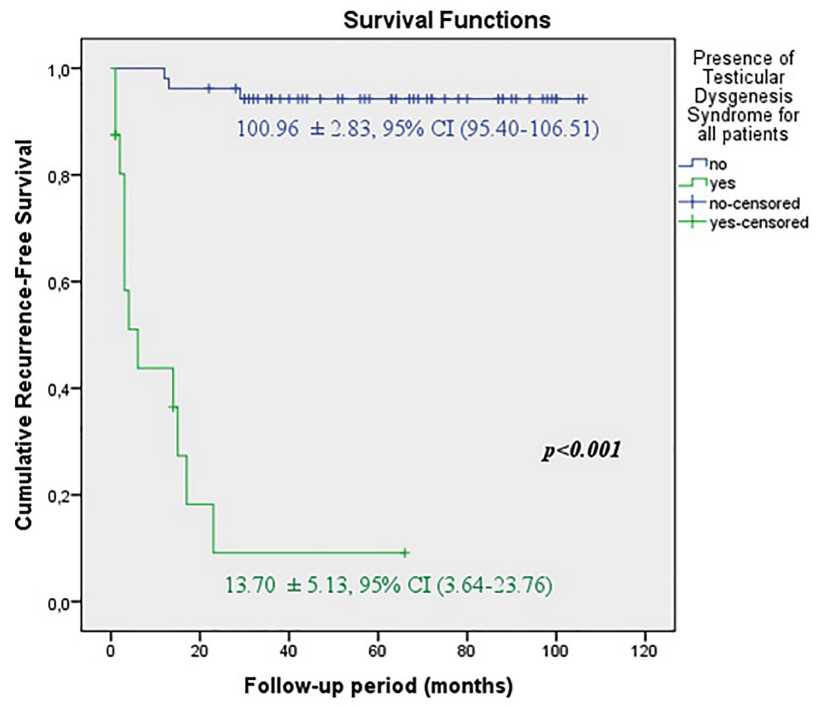

Figure 2B - Kaplan-Meier plots of metastasis-free survival according to presence of Testicular Dysgenesis Syndrome for all patients.

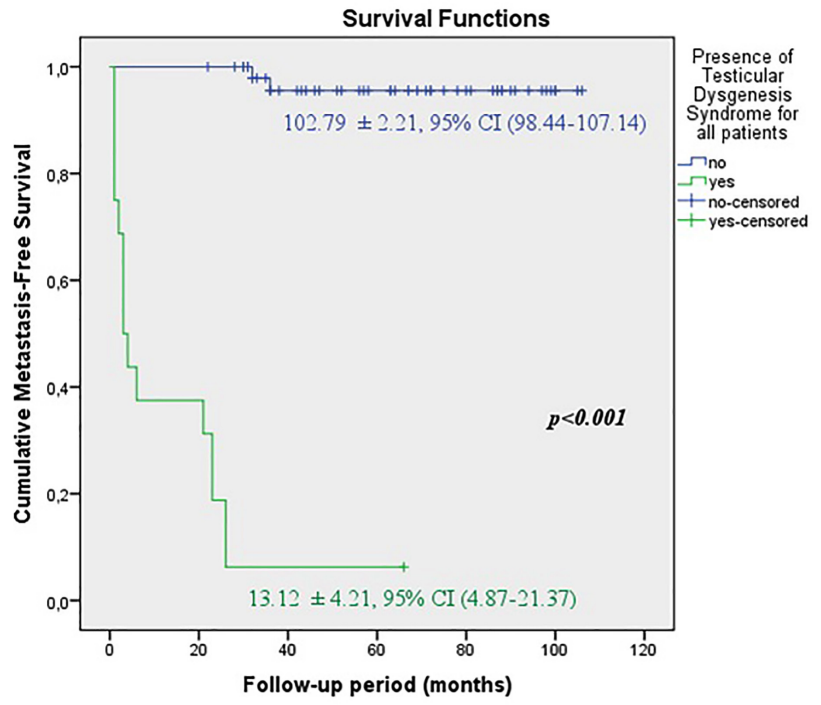

(12). Although most of these disorders are assumed to be associated with TDS, further studies are needed to make the definition of TDS widely acceptable (13).

It is thought that embryonic hormonal disturbances related to androgens play a role on abnormal differentiation of primordial germ cells (14). These are usually manifested by antenatal origin. Undescended testis and hypospadias give
Figure 2C - Kaplan-Meier plots of cancer-specific survival according to presence of Testicular Dysgenesis Syndrome for all patients.

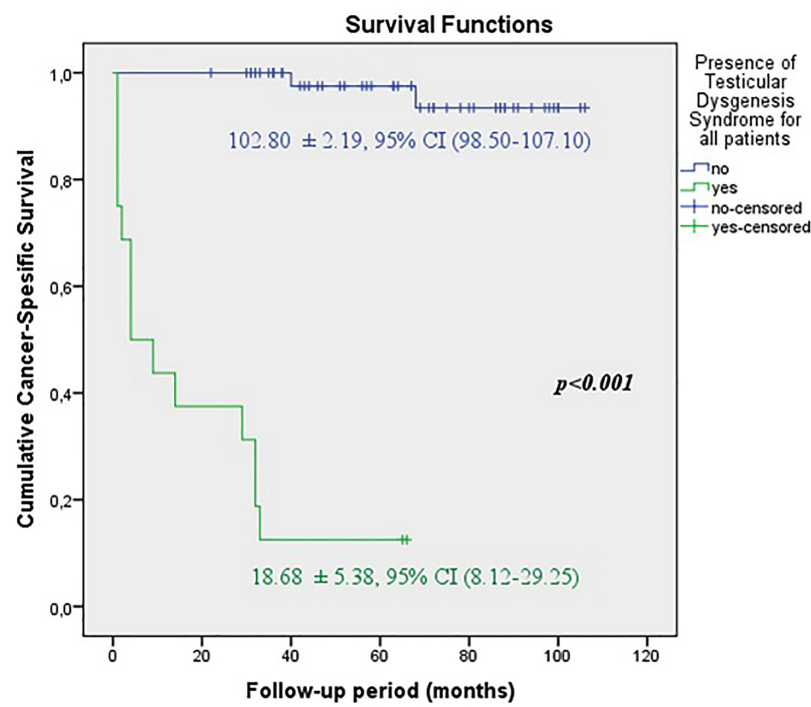

symptoms at neonatal period whereas poor quality of semen and development of TGCT manifest after puberty (9). Animal models and epidemiological researches have revealed that deficiencies in the production of androgens, disorders of androgen receptor expression, disturbance in androgen levels, exposure to anti-androgenic or estrogenic disruptors were attributed to the pathogenesis of TDS $(6,15)$. These factors are blamed for causing dysfunctions and dysregulation of Leydig and Sertoli cells. As a result, disruption of testicular differentiation and development give rise to impairment of normal gonadal maturation. Consequently, irreversible testicular dysgenesis is unavoidable and it results in genital malformation (such as hypospadias and undescended testis), impaired spermatogenesis and TGCT (7). TDS is predominantly triggered by environmental exposure, genetic and lifestyle factors as well as embryonic hormonal disturbances. All of these predisposing factors similarly affect the pathophysiology of TDS.

Skakkebaek et al. (16) re-analysed 20 testicular biopsies which were derived from patients with infertility, undescended testis and hypospadias. TGCT was detected in $45 \%$ of patients. But they did not evaluate the relation between presence of TDS and TGCT prognosis. Guminska et al. (17) detected that testes with disturbed spermatogenesis 
Figure 3A - Kaplan-Meier plots of recurrence-free survival according to presence of Testicular Dysgenesis Syndrome for patients with seminoma.

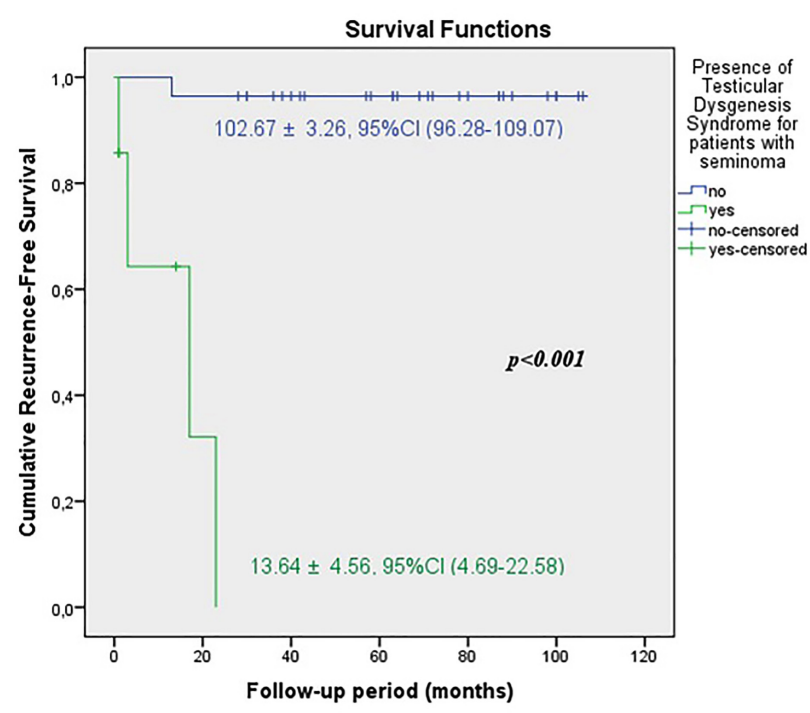

Figure 3B - Kaplan-Meier plots of metastasis-free survival according to presence of Testicular Dysgenesis Syndrome for patients with seminoma.

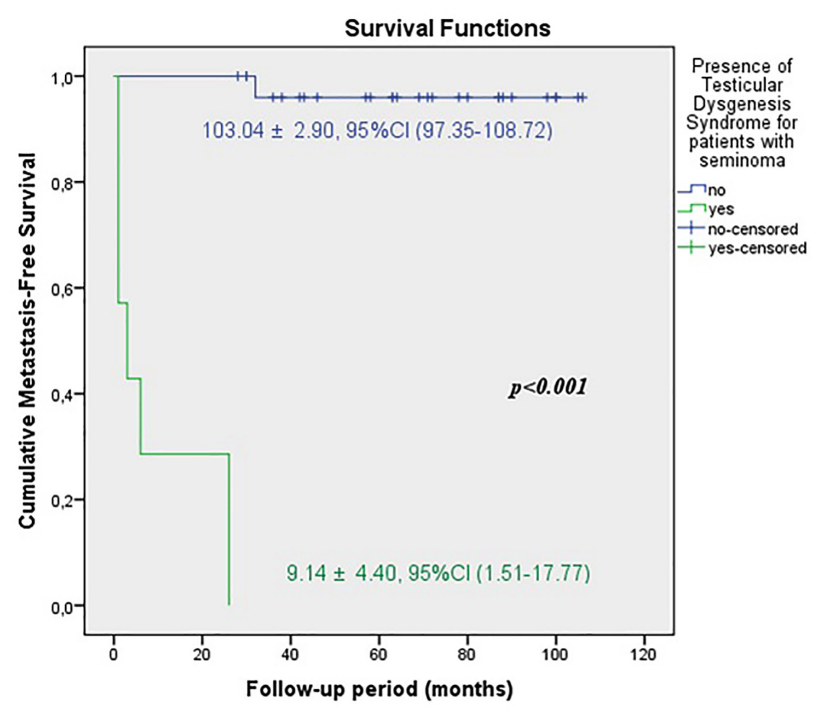

were more prone to development of TGCT. They investigated morphometric analysis of seminiferous epithelium, qualitative and quantitative features of Leydig cells, seminiferous tubules diameter and thickness of tubular wall. It was shown that poor testicular histomorphological features related to testicular dysgenesis increased the incidence of
Figure 3C - Kaplan-Meier plots of cancer-specific survival according to presence of Testicular Dysgenesis Syndrome for patients with seminoma.

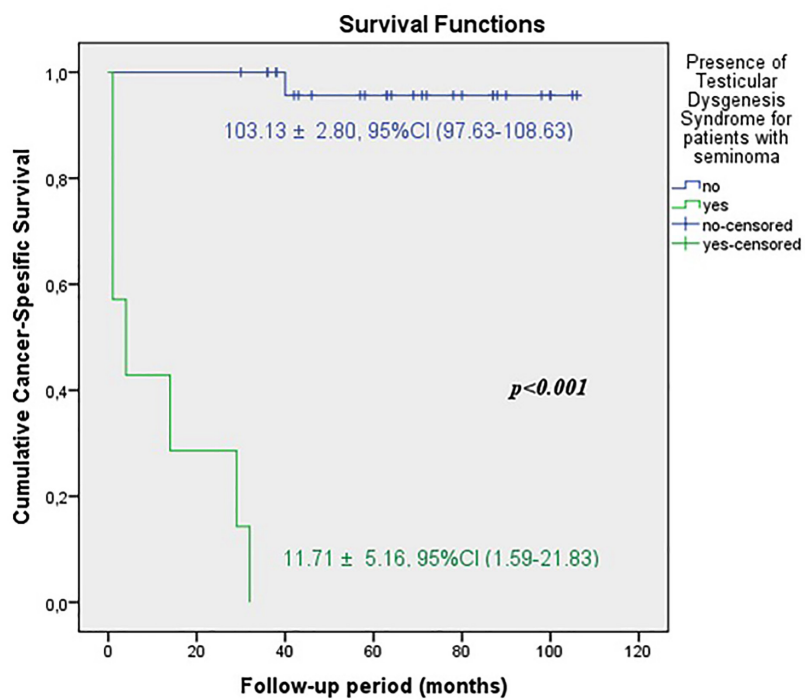

TGCT but they did not worsen the tumor prognosis.

Another source that supports the biological mechanism of TDS, can be attributed to our knowledge about testicular microlithiasis (TM). TM which is detected incidentally during the scrotal ultrasound, is a rare condition. It is observed around 0.6-9.0\% in symptomatic male adults and around 2.4-5.6\% in asymptomatic males (17). Although the presence of TM alone is not an indication for further investigation, the presence of other risk factors carries risk for TGCT development. These risk factors include history of previous TGCT, undescended testis, orchidopexy, testicular atrophy (testicular volume $<12 \mathrm{~mL}$ ) and subfertility (18). As it can be understood, the risk of TGCT increases in the presence of undescended testis and subfertility (19). From this point of view, we can think that embryological development and pathogenesis of all these disorders mentioned above is caused by a common fetal origin. This condition can be interpreted as supporting the TDS hypothesis (20).

It should be known that TDS hypothesis does not mean that all affected men develop all four components (21). A very broad variety of phenotypes can be seen in TDS. This wide spectrum ranges from genetically determined "Disorders of Sex Development" to mild forms such as slightly 
Figure 4A - Kaplan-Meier plots of recurrence-free survival according to presence of Testicular Dysgenesis Syndrome for patients with non-seminoma.

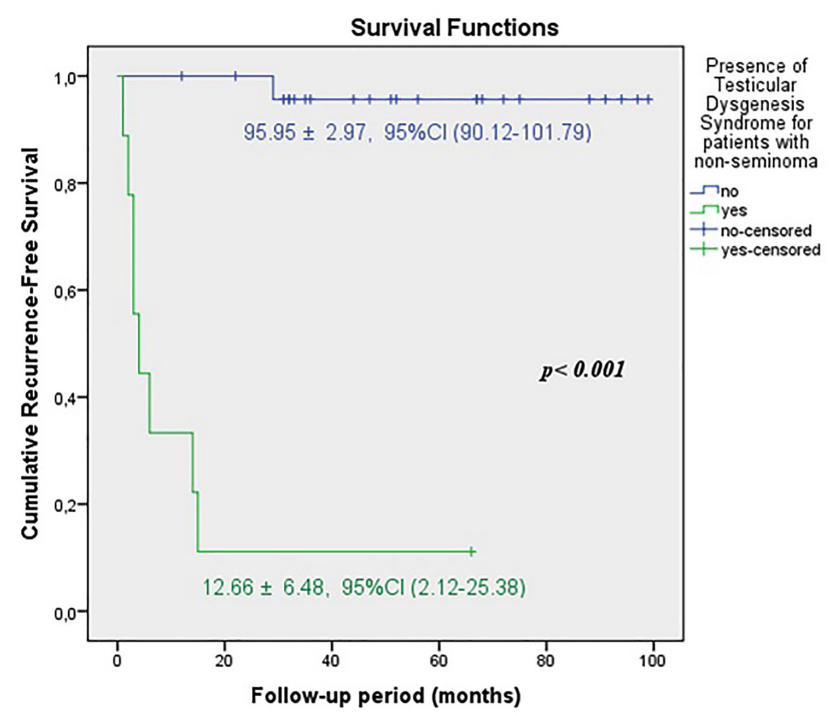

Figure 4B - Kaplan-Meier plots of metastasis-free survival according to presence of Testicular Dysgenesis Syndrome for patients with non-seminoma.

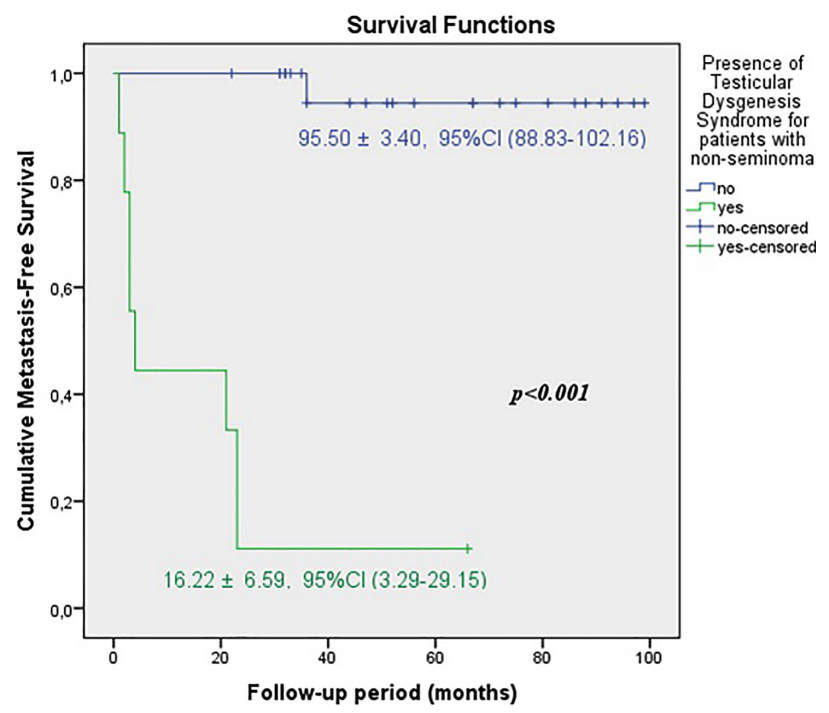

decreased spermatogenesis (5). One component of TDS may increase the possibility of other components' existence. Especially, if there are more than one component, the presence of other components should be examined more carefully to detect TDS (22).
Figure 4C - Kaplan-Meier plots of cancer-specific survival according to presence of Testicular Dysgenesis Syndrome for patients with non-seminoma.

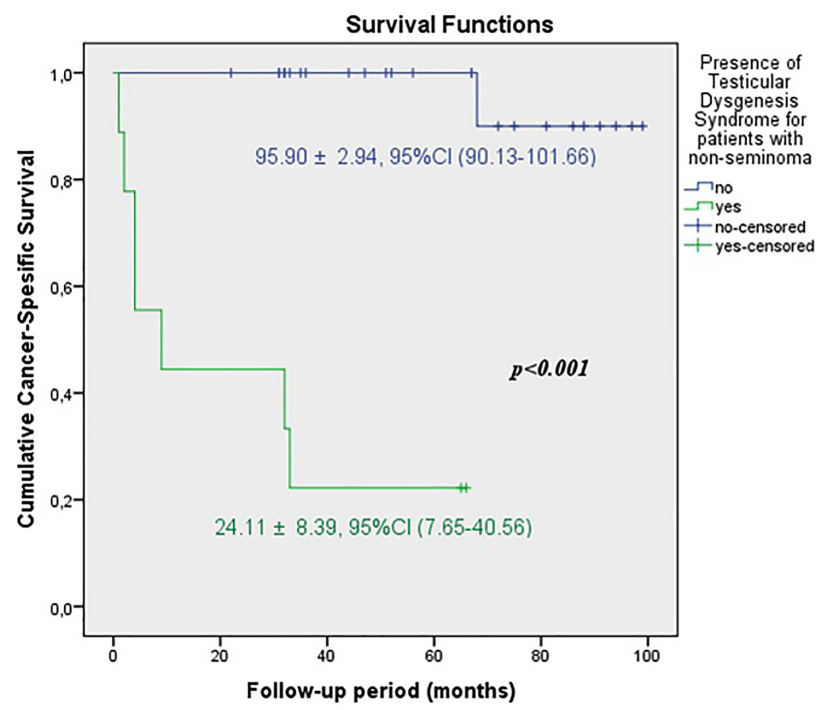

Environmental factors and genetic susceptibility are responsible for the etiology of TDS and TGCT (15). In literature, there are many animal models and epidemiological studies demonstrating this relationship $(13,15)$. Current animal models, involving fetal exposure to "Di-n-butyl phthalate" have been highlighting that environmental factors are most likely responsible for TDS and TGCT $(4,5)$. Translation of the animal model's findings to the human biology have been linked to TDS (4). But we have found no detailed studies investigating whether TDS or its components affect the oncological outcomes of TGCT.

Cure is achievable in 95\% of all patients with TGCT. At the time of diagnosis, 75-80\% of seminomas are stage I. In this group, rete testis invasion and/ or tumor size larger than $4 \mathrm{~cm}$ are risk factors that predict relapse and occult metastasis. In the follow-up periods of seminomas after adjuvant therapy, systemic recurrence rate was 1-4\%, while occult metastasis rate was $10-15 \%$. If any adjuvant treatments are not given to the patients with risk factors, the rate of local recurrence or retroperitoneal metastasis in five years is $15-20 \%$ (23). 55\% of non-seminomas are stage I at the time of diagnosis. The worst risk factor that predict relapse and occult metastasis is LVI for non-seminomas, while other important prognostic 
risk factors are percentage of embryonal carcinoma $>50 \%$ and a proliferation rate $>70 \%$. More than 30\% of them have occult metastasis at diagnosis. 70\% of them can develop local recurrence if any adjuvant treatments are not performed to the patients with risk factors. In the presence of LVI, systemic relapse rate was $14-22 \%$ and occult metastasis rate was $48 \%$ (24).

The local recurrence rates were reported as 9-24\% in stage IIA/B, whereas the cure rate is approximately $80 \%$ in stage IIC/III, despite the frontline and salvage chemotherapy (25). In metastatic disease, 5-year survival rates were reported by the International Germ Cell Cancer Collaboration Group to be $91 \%$ in the favorable risk group, 79\% in the intermediate risk group and 48\% in the poor risk group (25).

In our study, during median 57 (6-106) months follow-up in all patients, local recurrence rate was $21.7 \%$, distant metastasis rate was 24.6\%, 5-year cancer specific survival CSS rate was $76.8 \%$. When our patients were divided into two groups as early and advanced stages, the rates of local recurrence, distant metastasis and 5-year cancer specific survival were 9.1\%, 9.1\%, 90.9\% for early stage respectively, whereas the rates were $33.3 \%, 38.9 \%$ and $63.9 \%$ for advanced stage. The duration of recurrence-free survival RFS $(96.57 \pm$ 4.65 months), metastasis-free survival MFS (96.99 \pm 4.43 months), cancer-specific survival CSS (96.67 \pm 4.57 months) were observed significantly higher in early stage. Although our survival rates are less than the rates in the current literature (26), this may be explained by the small patients populations and short follow-up periods.

Undescended testis is known to be an important risk factor for the development of TGCT. The relative risk of TGCT was 2.23 even if patients underwent orchiopexy before 13 years old (27). Moirano et al. (28) observed that undescended testis was higher in TGCT group (11.4\%) than in healthy control group (3.0\%). Hanson et al. (29) detected an increased risk of testicular cancer (hazard rate of 3.3) in subfertile men when compared with fertile men (29). In addition, hypospadias was found associated with an increased relative risk for TGCT development (hazard rate of 2.13) (30).

We could not evaluate whether undescended testis, disorders of semen parameters and hy- pospadias were risk factors for the development of TGCT because we did not have a healthy control group. We compared these three components in terms of tumor stages. When these components were analyzed individually, we did not find significantly differences between early and advanced stage groups. But the rate of TDS was significantly higher in patients with advanced stage. This finding suggested that even if the components alone did not contain poor prognostic features for TGCT development, a significant increase was observed in tumor stages in the patients diagnosed with TDS (having more than one component).

In subgroup analysis, we divided patients into two groups according to presence of TDS. Although the small numbers of patients in the TDS group decreased the statistical power of the study, we found significantly higher rates of local recurrence (75\% vs. 5.7), distant metastasis (93.6\% vs $3.8 \%)$ and cancer related mortality $(87.5 \%$ vs. $3.8 \%$ ) in TDS group rather than those without TDS. When we evaluated two different tumor types separately, in the presence of TDS, the rate of local recurrence (88.9\% vs. 57.1\%) was higher in non-seminomas; whereas distant metastasis (100\% vs. $88.9 \%)$ and cancer-specific mortality rates (100\% vs. $\mathbf{7 7 . 8} \%$ ) were higher in seminomas. It is obvious that these findings will be more reliable when a much larger patient population is evaluated.

To the best of our knowledge, this is the first study to evaluate the prognostic value of TDS components on TGCT prognosis and oncological outcomes. However, this study has some limitations. The main limitations of our study are retrospective, non randomized design with small patient population in a single center. Future studies that have larger numbers of patients with multicentre, prospective, randomized, controlled, long-term follow-up are needed to verify our results and explain more new details about this hypothesis, especially for the subgroup analysis with patients having TDS. We presented our findings as "Preliminary Results" because it was not easy to have comprehensive results due to small patient population and relatively short follow-up. Since this topic has not been studied before, we think that our findings as "Preliminary Results" may be a step for further studies. 
Table 4 - Predictive factors for local recurrence, distant metastases and cancer-specific survival.

\begin{tabular}{|c|c|c|c|c|c|c|c|c|}
\hline \multirow[t]{3}{*}{ All patients with testicular germ cell tumor } & \multicolumn{4}{|c|}{ Univariate Model } & \multicolumn{4}{|c|}{ Multivariate Model } \\
\hline & \multirow{3}{*}{$\mathrm{HR}$} & \multirow{2}{*}{\multicolumn{2}{|c|}{$\begin{array}{l}\text { \%95 Confidence } \\
\text { Interval }\end{array}$}} & \multirow{3}{*}{$p$} & \multirow{3}{*}{$H R$} & \multirow{2}{*}{\multicolumn{2}{|c|}{$\begin{array}{l}\text { \%95 Confidence } \\
\text { Interval }\end{array}$}} & \multirow{3}{*}{$\mathrm{p}$} \\
\hline & & & & & & & & \\
\hline Development of local recurrence & & Lower & Upper & & & Lower & Upper & \\
\hline Clinical stage & 12,471 & 2,320 & 34,624 & 0.005 & & & & \\
\hline$\beta$-hCG & 1,001 & 1,000 & 1,011 & 0.003 & & & & \\
\hline LDH & 1,009 & 1,000 & 1,019 & $<0.001$ & & & & \\
\hline Undescended testis & 20,238 & 9,128 & 106,902 & $<0.001$ & & & & \\
\hline Disorders of semen parameters & 7,250 & 2,359 & 22,281 & 0.001 & & & & \\
\hline Hypospadiass & 16,182 & 4,286 & 61,100 & $<0.001$ & & & & \\
\hline Atrophic testis & 11,186 & 3,641 & 34,373 & $<0.001$ & & & & \\
\hline Testicular Dysgenesis Syndrome & 31,911 & 12,414 & 289,130 & $<0.001$ & 31,911 & 12,414 & 289,130 & $<0.001$ \\
\hline \multirow[t]{2}{*}{ All patients with testicular germ cell tumor } & \multicolumn{3}{|c|}{ Univariate Model } & & \multicolumn{4}{|c|}{ Multivariate Model } \\
\hline & $H R$ & \multicolumn{2}{|c|}{$\begin{array}{c}\% 95 \text { Confidence } \\
\text { Interval }\end{array}$} & \multirow[t]{2}{*}{$p$} & \multirow{2}{*}{ HR } & \multicolumn{2}{|c|}{$\begin{array}{l}\text { \%95 Confidence } \\
\text { Interval }\end{array}$} & \multirow[t]{2}{*}{$p$} \\
\hline Development of distant metastasis & & Lower & Upper & & & Lower & Upper & \\
\hline Clinical stage & 14,988 & 5,575 & 36,668 & 0.001 & 12,827 & 4,186 & 36,738 & 0.019 \\
\hline$\beta$-hCG & 1,003 & 1,000 & 1,008 & 0.007 & & & & \\
\hline LDH & 1,004 & 1,000 & 1,017 & 0.001 & & & & \\
\hline Undescended testis & 11,966 & 5,069 & 44,184 & $<0.001$ & & & & \\
\hline Disorders of semen parameters & 12,928 & 5,316 & 41,917 & $<0.001$ & & & & \\
\hline Hypospadiass & 11,342 & 3,082 & 41,741 & $<0.001$ & & & & \\
\hline Atrophic testis & 11,626 & 4,009 & 33,711 & $<0.001$ & & & & \\
\hline Testicular Dysgenesis Syndrome & 35,120 & 15,785 & 357,499 & $<0.001$ & 35,120 & 15,785 & 357,499 & $<0.001$ \\
\hline \multirow[t]{3}{*}{ All patients with testicular germ cell tumor } & \multicolumn{3}{|c|}{ Univariate Model } & & \multicolumn{4}{|c|}{ Multivariate Model } \\
\hline & $\mathrm{HR}$ & \multicolumn{2}{|c|}{$\begin{array}{c}\% 95 \text { Confidence } \\
\text { Interval }\end{array}$} & \multirow{2}{*}{$\mathrm{p}$} & \multirow{2}{*}{$H R$} & \multicolumn{2}{|c|}{$\begin{array}{c}\text { \%95 Confidence } \\
\text { Interval }\end{array}$} & \multirow{2}{*}{$p$} \\
\hline & & Lower & Upper & & & Lower & Upper & \\
\hline Clinical stage & 12,404 & 2,339 & 33,316 & 0.003 & & & & \\
\hline$\beta$-hCG & 1,002 & 1,000 & 1,016 & 0.006 & & & & \\
\hline LDH & 1,006 & 1,000 & 1,014 & 0.001 & & & & \\
\hline
\end{tabular}




\begin{tabular}{|c|c|c|c|c|c|c|c|c|c|}
\hline Undescended testis & \multicolumn{2}{|c|}{19,559} & 6,302 & 60,709 & $<0.001$ & & & & \\
\hline Disorders of semen parameters & \multicolumn{2}{|c|}{10,602} & 3,729 & 30,143 & $<0.001$ & & & & \\
\hline Hypospadiass & \multicolumn{2}{|c|}{12,398} & 3,317 & 46,342 & $<0.001$ & & & & \\
\hline Atrophic testis & \multicolumn{2}{|c|}{11,661} & 4,000 & 33,994 & $<0.001$ & & & & \\
\hline Testicular Dysgenesis Syndrome & \multicolumn{2}{|c|}{37,148} & 12,844 & 780,852 & $<0.001$ & 37,148 & 12,8 & 780,852 & $<0.001$ \\
\hline \multirow[t]{2}{*}{ Patients with seminoma } & \multicolumn{4}{|c|}{ Univariate Model } & & \multicolumn{4}{|c|}{ Multivariate Model } \\
\hline & \multirow{2}{*}{$\mathrm{HR}$} & \multicolumn{2}{|c|}{$\begin{array}{l}\% 95 \text { Confidence } \\
\text { Interval }\end{array}$} & \multirow{2}{*}{$p$} & & \multirow{2}{*}{$\mathrm{HR}$} & \multicolumn{2}{|c|}{$\begin{array}{l}\% 95 \text { Confidence } \\
\text { Interval }\end{array}$} & \multirow{2}{*}{$p$} \\
\hline Development of local recurrence & & Lower & Upper & & & & Lower & Upper & \\
\hline Clinical stage & 12,564 & 0,926 & 7,101 & 0.047 & & & & & \\
\hline LDH & 1,001 & 1,000 & 1,002 & 0.038 & & & & & \\
\hline Undescended testis & 13,159 & 3,790 & 141,529 & 0.001 & & & & & \\
\hline Disorders of semen parameters & 9,347 & 1,449 & 60,312 & 0.019 & & & & & \\
\hline Hypospadiass & 15,641 & 3,555 & 184,944 & 0.001 & & & & & \\
\hline Atrophic testis & 18,323 & 2,931 & 114,540 & 0.002 & & & & & \\
\hline Testicular Dysgenesis Syndrome & 30,628 & 4,635 & 129,742 & 0.001 & & 30,628 & 4,635 & 129,742 & 0.001 \\
\hline \multirow[t]{2}{*}{ Patients with seminoma } & \multicolumn{4}{|c|}{ Univariate Model } & & \multicolumn{4}{|c|}{ Multivariate Model } \\
\hline & \multicolumn{3}{|c|}{$\begin{array}{l}\text { \%95 Confidence } \\
\text { Interval }\end{array}$} & \multirow{2}{*}{$p$} & & \multirow{2}{*}{$\mathrm{HR}$} & \multicolumn{2}{|c|}{$\begin{array}{c}\% 95 \text { Confidence } \\
\text { Interval }\end{array}$} & \multirow{2}{*}{$p$} \\
\hline Development of distant metastasis & & Lower & Upper & & & & Lower & Upper & \\
\hline Clinical stage & 12,766 & 1,179 & 6,493 & 0.019 & & & & & \\
\hline$\beta$-hCG & 1,005 & 1,001 & 1,010 & 0.020 & & & & & \\
\hline LDH & 1,002 & 1,000 & 1,009 & 0.016 & & & & & \\
\hline Undescended testis & 9,470 & 2,111 & 42,487 & 0.003 & & & & & \\
\hline Disorders of semen parameters & 11,228 & 5,605 & 43,994 & $<0.001$ & & & & & \\
\hline Hypospadiass & 9,076 & 1,735 & 47,469 & 0.009 & & & & & \\
\hline Atrophic testis & 13,015 & 2,880 & 58,805 & 0.001 & & & & & \\
\hline Testicular Dysgenesis Syndrome & 44,261 & 5,898 & 411,469 & $<0.001$ & & 44,261 & 5,898 & 411,469 & $<0.001$ \\
\hline
\end{tabular}




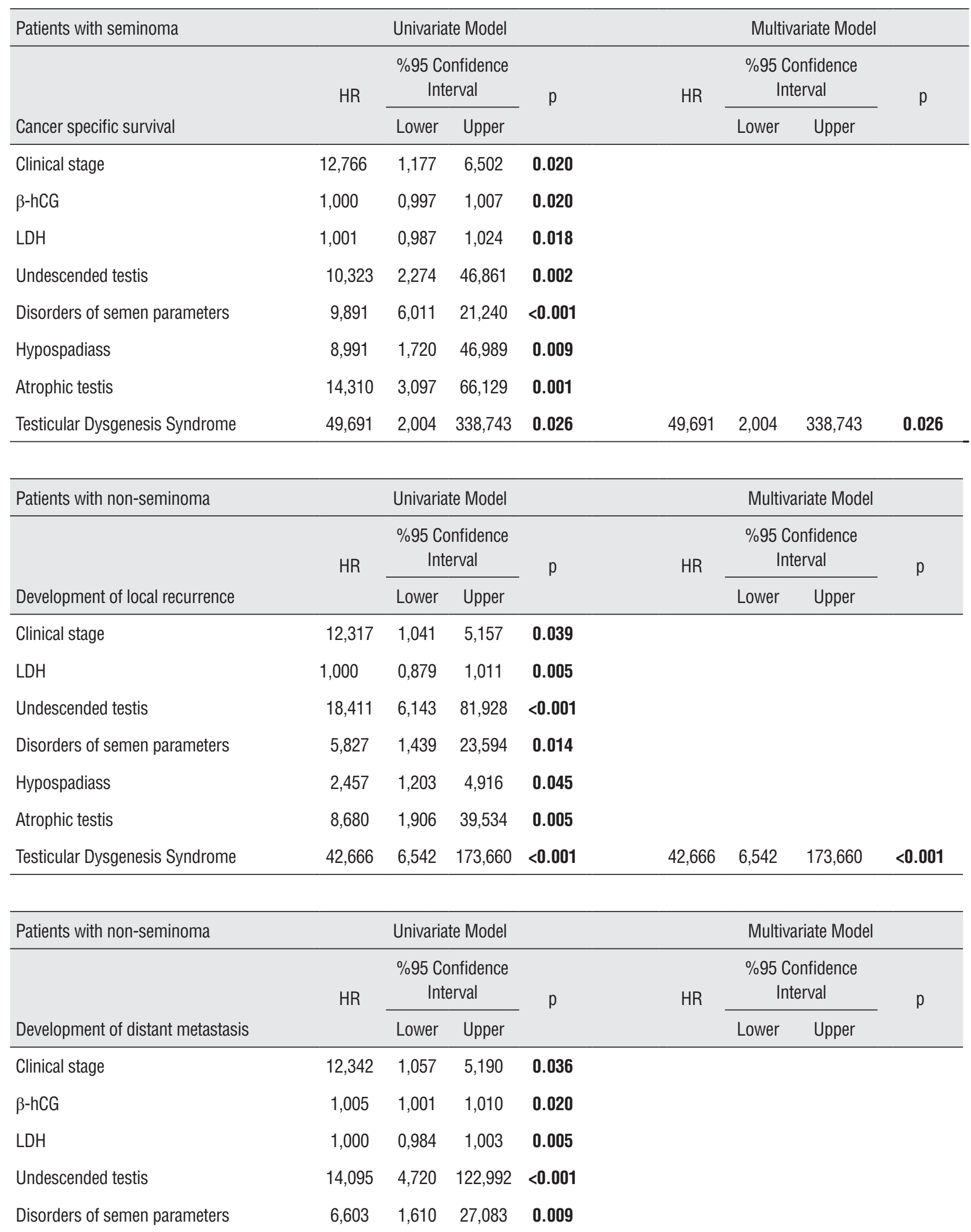




\begin{tabular}{|c|c|c|c|c|c|c|c|c|}
\hline Hypospadiass & 2,123 & 1,015 & 3,356 & 0.042 & & & & \\
\hline Atrophic testis & 6,456 & 1,538 & 27,102 & 0.011 & & & & \\
\hline Testicular Dysgenesis Syndrome & 28,536 & 9,458 & 39,177 & 0.046 & 28,536 & 9,458 & 39,177 & 0.046 \\
\hline \multirow[t]{2}{*}{ Patients with non-seminoma } & \multicolumn{4}{|c|}{ Univariate Model } & \multicolumn{4}{|c|}{ Multivariate Model } \\
\hline & $\mathrm{HR}$ & $\begin{array}{r}\% 95 \mathrm{Cc} \\
\operatorname{lnt}\end{array}$ & $\begin{array}{l}\text { nfidence } \\
\text { rval }\end{array}$ & $p$ & $\mathrm{HR}$ & $\% 95$ & $\begin{array}{l}\text { fidence } \\
\text { rval }\end{array}$ & $p$ \\
\hline Cancer specific survival & & Lower & Upper & & & Lower & Upper & \\
\hline Clinical stage & 12,238 & 0,969 & 5,168 & 0.039 & & & & \\
\hline$\beta$-hCG & 1,000 & 0,997 & 1,007 & 0.020 & & & & \\
\hline $\mathrm{LDH}$ & 1,002 & 0,802 & 1,011 & 0.005 & & & & \\
\hline Undescended testis & 15,891 & 5,827 & 44,495 & $<0.001$ & & & & \\
\hline Disorders of semen parameters & 4,095 & 0,790 & 21,219 & 0.033 & & & & \\
\hline Hypospadiass & 1,402 & 1,017 & 3,916 & 0.041 & & & & \\
\hline Atrophic testis & 8,372 & 1,849 & 37,908 & 0.006 & & & & \\
\hline Testicular Dysgenesis Syndrome & 25,634 & 2,479 & 39,951 & 0.034 & 25,634 & 2,479 & 39,951 & 0.034 \\
\hline
\end{tabular}

\section{CONCLUSIONS}

In conclusion, although there have been many controversial views on TDS since the last two decades, most studies have shown the relationship between the four components of TDS. We observed the fact that TDS was detected to be higher in advanced stages of TGCT. Moreover, we have seen a significant increase in the rates of local recurrence, distant metastasis and cancer specific mortality in the presence of TDS.

\section{ABBREVIATIONS}

AFP = Alpha-fetoprotein;

$\beta$-hCG = Beta human chorionic gonadotropin;

$\mathrm{LDH}=$ Lactate dehydrogenase;

LVI = lymphovascular invasion;

TDS = Testicular Dysgenesis Syndrome;

TGCT $=$ Testicular germ cell tumor;

$\mathrm{TM}=$ Testicular microlithiasis.

\section{CONFLICT OF INTEREST}

None declared.

\section{REFERENCES}

1. Skakkebaek NE, Rajpert-De Meyts E, Main KM. Testicular dysgenesis syndrome: an increasingly common developmental disorder with environmental aspects. Hum Reprod. 2001;16:972-8.

2. Jørgensen N, Asklund C, Carlsen E, Skakkebaek NE. Coordinated European investigations of semen quality: results from studies of Scandinavian young men is a matter of concern. Int J Androl. 2006;29:54-61; discussion 105-8.

3. Sharpe RM, Skakkebaek NE. Testicular dysgenesis syndrome: mechanistic insights and potential new downstream effects. Fertil Steril. 2008;89(2 Suppl):e33-8.

4. van den Driesche S, Kilcoyne KR, Wagner I, Rebourcet D, Boyle A, Mitchell R, et al. Experimentally induced testicular dysgenesis syndrome originates in the masculinization programming window. JCI Insight. 2017;2:e91204. 
5. Jørgensen N, Rajpert-De Meyts E, Main KM, Skakkebaek NE. Testicular dysgenesis syndrome comprises some but not all cases of hypospadias and impaired spermatogenesis. Int $\mathrm{J}$ Androl. 2010;33:298-303.

6. van den Driesche S, Kolovos P, Platts S, Drake AJ, Sharpe RM. Inter-relationship between testicular dysgenesis and Leydig cell function in the masculinization programming window in the rat. PLoS One. 2012;7:e30111.

7. Söder 0. Sexual dimorphism of gonadal development. Best Pract Res Clin Endocrinol Metab. 2007;21:381-91.

8. Akre 0, Richiardi L. Does a testicular dysgenesis syndrome exist? Hum Reprod. 2009;24:2053-60.

9. Spiller CM, Bowles J. Germ cell neoplasia in situ: The precursor cell for invasive germ cell tumors of the testis. Int J Biochem Cell Biol. 2017;86:22-25.

10. McGlynn KA, Cook MB. Etiologic factors in testicular germcell tumors. Future Oncol. 2009;5:1389-402.

11. Toppari J, Virtanen HE, Main KM, Skakkebaek NE. Cryptorchidism and hypospadias as a sign of testicular dysgenesis syndrome (TDS): environmental connection. Birth Defects Res A Clin Mol Teratol. 2010;88:910-9.

12. Erdemir F, Fırat F, Gençten Y. The Evaluation and Clinical Significance of Sperm Morphology. Turk Urol Sem. 2011;2:11-7.

13. Rajpert-De Meyts E. Developmental model for the pathogenesis of testicular carcinoma in situ: genetic and environmental aspects. Hum Reprod Update. 2006;12:303-23.

14. Baskin LS. Hypospadias and urethral development. J Urol. 2000;163:951-6.

15. Xing JS, Bai ZM. Is testicular dysgenesis syndrome a genetic, endocrine, or environmental disease, or an unexplained reproductive disorder? Life Sci. 2018;194:120-129.

16. Skakkebaek NE, Holm M, Hoei-Hansen C, Jørgensen $\mathrm{N}$, Rajpert-De Meyts E. Association between testicular dysgenesis syndrome (TDS) and testicular neoplasia: evidence from 20 adult patients with signs of maldevelopment of the testis. APMIS. 2003;111:1-9; discussion 9-11.

17. Guminska A, Oszukowska E, Kuzanski W, Sosnowski M, Wolski JK, Walczak-Jedrzejowska R, et al. Less advanced testicular dysgenesis is associated by a higher prevalence of germ cell neoplasia. Int J Androl. 2010;33:e153-62.

18. Balawender K, Orkisz S, Wisz P. Testicular microlithiasis: what urologists should know. A review of the current literature. Cent European J Urol. 2018;71:310-314.

19. Pedersen MR, Rafaelsen SR, Møller H, Vedsted P, Osther PJ. Testicular microlithiasis and testicular cancer: review of the literature. Int Urol Nephrol. 2016;48:1079-86.
20. Dantsev IS, Ivkin EV, Tryakin AA, Godlevski DN, Latyshev OY, Rudenko VV, et5 al. Genes associated with testicular germ cell tumors and testicular dysgenesis in patients with testicular microlithiasis. Asian J Androl. 2018;20:593-599.

21. Mahood IK, Hallmark N, McKinnell C, Walker M, Fisher JS, Sharpe RM. Abnormal Leydig Cell aggregation in the fetal testis of rats exposed to di (n-butyl) phthalate and its possible role in testicular dysgenesis. Endocrinology. 2005;146:613-23.

22. Hoei-Hansen CE, Sommer P, Rajpert-De Meyts E, Skakkebaek NE. A rare diagnosis: testicular dysgenesis with carcinoma in situ detected in a patient with ultrasonic microlithiasis. Asian J Androl. 2005;7:445-7.

23. Shelley MD, Burgon K, Mason MD. Treatment of testicular germ-cell cancer: a cochrane evidence-based systematic review. Cancer Treat Rev. 2002;28:237-53.

24. Ondrusova M, Suchansky M, Psota M, Zeleny T, Ondrus D. Late relapse in stage I of nonseminomatous germ cell testicular cancer on surveillance. Bratisl Lek Listy. 2018;119:3-5.

25. Adra N, Einhorn LH. Testicular cancer update. Clin Adv Hematol Oncol. 2017;15:386-396.

26. Withington J, Cole AP, Meyer CP, Seisen T, Schmid M, Lipsitz $\mathrm{SR}$, et al. Comparison of testis cancer-specific survival: an analysis of national cancer registry data from the USA, UK and Germany. BJU Int. 2019;123:385-387.

27. Pettersson A, Richiardi L, Nordenskjold A, Kaijser M, Akre 0. Age at surgery for undescended testis and risk of testicular cancer. N Engl J Med. 2007;356:1835-41.

28. Moirano G, Zugna D, Grasso C, Mirabelli D, Lista P, Ciuffreda $\mathrm{L}$, et al. Postnatal risk factors for testicular cancer: The EPSAM case-control study. Int J Cancer. 2017;141:1803-1810.

29. Hanson HA, Anderson RE, Aston KI, Carrell DT, Smith KR, Hotaling JM. Subfertility increases risk of testicular cancer: evidence from population-based semen samples. Fertil Steril. 2016;105:322-8.e1.

30. Schnack TH, Poulsen G, Myrup C, Wohlfahrt J, Melbye M. Familial coaggregation of cryptorchidism, hypospadias, and testicular germ cell cancer: a nationwide cohort study. J Natl Cancer Inst. 2010;102:187-92.

Correspondence address: Ismail Selvi, MD, FEBU Department of Urology, Karabuk University Training and Research Hospital, Karabuk, 78200, Turkey Fax: + $900370412-5628$ E-mail: ismselvi33@hotmail.com 